Article

\title{
Determinant Factors of the Adoption of Improved Maize Seeds in Southern Mexico: A Survival Analysis Approach
}

\author{
Blanca Isabel Sánchez-Toledano ${ }^{1,2, * \mathbb{C}}$, Zein Kallas ${ }^{1} \mathbb{D}$, Oscar Palmeros Rojas $^{3}$ and \\ José M. Gil ${ }^{1}$ (D) \\ 1 Centre for Agro-Food Economy and Development (CREDA-UPC-IRTA), Universidad Politécnica de \\ Cataluña, Parc Mediterrani de la Tecnologia, Edifici ESAB, C/Esteve Terrades, 08860 Casteldefells, \\ Barcelona, Spain; zein.kallas@upc.edu (Z.K.); chema.gil@upc.edu (J.M.G.) \\ 2 Campo Experimental Zacatecas-INIFAP, Apartado Postal Núm. 18, Calera de Víctor Rosales, \\ Zacatecas 98500, Mexico \\ 3 Departamento de Matemáticas, Universidad Autónoma Chapingo, Estado de Mexico, \\ Km 38.5 carretera Mexico, Texcoco 56230, Mexico; opalmeros_rojas@hotmail.com \\ * Correspondence: sugammx@hotmail.com; Tel.: +11-52-80008-82222 (ext. 82322)
}

Received: 21 August 2018; Accepted: 29 September 2018; Published: 2 October 2018

\begin{abstract}
Maize is the most important and strategic crop in Mexico, however, this sector suffers from low productivity. Among the various strategies to improve yield by hectare, improved maize seeds play an important role. In this context, adoption studies in Mexico of these types of seeds are scarce and in general do not jointly account for the timing of adoption factors affecting the adoption decision. This study analysed the determinants of the adoption rates of improved seeds using the survival analysis method. Farm-level data were collected in 2015 through a questionnaire administered to 200 maize farmers in Chiapas, Mexico. Our results showed that $60 \%$ of the farmers who adopted the improved seeds reached the decision within a 10 years' period. Specifically, young farmers with a low number of family members from several generations of agricultural work, who exhibited positive attitudes towards innovation and with low risk perception were likely to adopt the new varieties. Furthermore, results showed that the NAFTA Mexican reform of agricultural policy in 1994 negatively affected the adoption rate of improved seeds. Improving the maize yield requires adequate extension information systems that allow farmers to receive more information on the importance of adoption innovation as well as help them market their products.
\end{abstract}

Keywords: adoption; improved maize seed; survival analysis; Mexico

\section{Introduction}

The globalization and liberalization of food markets as well as the agriculture sector in particular have created a scenario where the predominant position is to achieve food security from comparative and competitive advantages. In light of this, Mexico has resorted to importing maize (14.1 million tons in 2016) [1]. In 2016, maize (Zea mays L.) production in Mexico was estimated at 28.2 million tons, with $2.95 \mathrm{t} / \mathrm{ha}$ and an increase of $77 \%$ in imports [1]. The low level of maize productivity in Mexico has become a national food security issue as maize has been the main food product, especially in rural areas with extreme poverty and higher marginalization. The annual consumption of maize is estimated at $123 \mathrm{~kg}$ per capita, well above the worldwide average of $16.8 \mathrm{~kg}$ per capita [2].

The UN Food and Agriculture Organization (FAO) has estimated that maize production will not satisfy the global demand by 2050 as a result of climate change, the shortage of production inputs and the emergence of new pests and diseases [3]. Consequently, the price of basic grains 
will increase significantly on the international market, making the import of maize into Mexico very costly [4]. Therefore, improving maize productivity is indispensable to meet future food demand and to ensure sustainable production. The supply of healthy and safe food at a reasonable cost of the production systems are the socio-economic dimensions of sustainable agriculture [5]. To improve and ensure Mexican food security policy, maize production in country should increase to meet the increasing demand for maize. This strategy is particularly relevant when the reduction of arable land due to population growth is taken into consideration. Accordingly, increasing productivity through the adoption of technological innovation is fundamental in mediating these issues. The production of maize in Mexico is mostly carried out in non-irrigated lands by small producers (less than five hectares) and low yields. Turrent et al. [6] estimated that the potential for maize production in Mexico was 52 million tons, of which 28 million would be feasible to achieve in the short term. This short-term increase could be reached without increasing the amount of agricultural land used, without cultivating transgenic maize and with good agronomic practices. The conservation of productive resources and the environment constitute the two basic requirements of the ecological variable of sustainable agriculture [5]. Therefore, increasing maize production and yields are feasible options under non-irrigated conditions, especially through the adoption of improved seeds [7].

The improvements in maize seed in Mexico in the last fifty years has been one of the most studied topics in agricultural research, partnered with the objective to increase its adoption. A number of hybrids and open-pollinated varieties (OPVs) have been developed and disseminated for boosting production under various environmental conditions. Luna et al. [8] noted that the first improved maize varieties were developed in 1947. Currently, 1595 varieties of maize have already been released [9]. Nevertheless, acceptance of the improved seeds remains low amongst farmers, particularly small farmers. The planted area only represents 2.7 million hectares of a total of 6.1 million hectares of total production in Mexico [10]. To illustrate, the state of Chiapas has the largest demand for maize seed and the highest potential for increasing production, however, it is still one of the states with the lowest adoption rates of improved seeds $(30 \%)$ due to the low-perceived advantage of this technology [1]. Furthermore, there are a wide range of factors that may affect the ability of farmers to adopt technologies at the farm level such as socio-economical, institutional, cultural and political conditions and variables [11]. The price of the seed and the cost of innovation are key factors at play in the adoption of improved seeds in Mexico. Nevertheless, there is evidence that small-scale farmers are willing to use improved seed if it clearly increases yields and if innovations are affordable, as shown in studies in El Salvador, Zimbabwe, China and Kenya [12].

The success of the research and development of innovation usually occurs when farmers make effective use of technology. Cimmyt [13] noted that all institutions involved in the generation and the transfer of agricultural technology must be able to design and conduct studies that clearly identify the adoption rate and explain the motivations and determinant factors of farmers. Although several studies have examined the adoption and diffusion of new varieties, these studies have been limited to determining the rate of adoption and the factors that affected the decisions at a given time, generally through statistical analysis based mainly on probit, logit, or tobit models [14]. The length of time or duration that farmers wait before adopting a new technology may be expected to depend on a number of economic, social and institutional factors, some of which vary with time (for example, the age of the farmer and major reform, policy and regulation introduction) and some of which do not (for example, the sex of the farmer, education level). This paper examined the adoption behaviour over time of improved maize seeds of smallholder farmers in the Chiapas, Mexico using survival analysis, a statistical technique which provides numerical and graphical summaries of duration data and allows the researcher to investigate the effects of explanatory variables on the duration of stay of an individual in a given state. Duration analysis, therefore, allowed us to determine not only why farmers adopted improved maize seeds but also when they adopted and what factors influenced the observed time patterns. Additionally, one of the advantages of survival analysis is that it allows for the study of the heterogeneous decision of adoption [15]. Up to now, few studies have followed this approach at a 
Mexican agricultural level. Hattam et al. [16] analysed organic adoption decisions using a rich set of time-to-organic durations collected from avocado small-holders in Michoacán, Mexico. In this context, the analysis of the adoption behaviour of maize seed farmers is still scarce. The survival analysis method is a method of statistical treatment of survival times, which not only makes proper allowances for those observations that are censored but also makes use of the information from subjects up to the time when they are censored. This technique is a useful tool that may play a significant role in generating evidence-based information on survival time.

Thus, this work contributes to the previous literature by extending the survival analysis traditional studies to consider farmer attitudes and risk perceptions as relevant factors in explaining the decision to adopt. In this regard, attitudes and preferences are important determinants of adoption decisions $[17,18]$. To capture and simplify this complexity, the Principal Components Analysis (PCA) was used; the resulting factors from PCA are used as explanatory variables of improved seed adoption. Furthermore, the research is expected to provide the foundation for greater efficiency of agricultural policies as well as help generate and transfer technologies. Importantly, a better understanding of the underlying dynamics of the adoption may help improve strategies to accelerate adoption.

\section{Adoption of Improved Seeds}

One of the factors that limits the growth of the Mexican agricultural sector is the lack of generation and, particularly, the adoption of new production technologies (30\%) [19]. Adoption is understood, in the context of technological innovations, as the process by which the agricultural producer replaces one activity with another, previously unknown. This implies learning and changing its production function [20].

The adoption of a technology is a dynamic process and in the context of risky production such as that of the agricultural sector, learning about the structure of the production process is important. Welch [21] suggests that farmers know that what is learned today is useful in the future and, therefore, they can deliberately experiment with the inputs, knowing that they will not be able to optimize in the short term but to discover more about the factors of production to help in the optimal operation of their system in the future.

Several studies $[22,23]$ have summarized the factors that influence adoption decisions in agriculture. The most relevant factors that can influence the decision to convert include: the characteristics of the farmer [13], the structure and management of the farm [24], information sources [25], risk [26], economic resources and availability of machinery [27] and attitudes and opinions [28].

In terms of yield, improved varieties have been shown to be significantly superior to native ones [6] but small producers often prefer their local varieties. This is mainly due to certain advantages such as adaptation to local climatic conditions and stability to climatic variability [6]. The preference of creole varieties occurs more frequently when farmers are located in isolated production areas and on slopes with poor soils [29]. So, the development of maize varieties based on the farmers' preferences and better adapted to new climatic conditions is vital for future food production [30,31]. The United Nations Organization mentions that in developing countries, only an average of $50 \%$ of the area of maize is cultivated with modern varieties including hybrids and improved free-pollinated varieties, while in developed countries the use of modern varieties is close to $100 \%$ [30].

Seed production in Mexico is in the hands of both the national and international private sector, which participates with $94 \%$ of the market while the public sector maintains $6 \%$. In Mexico, Bayer-Monsanto, DuPont, Syngenta and Dow AgroSciences dominate the market [32]. 
The sale prices of the improved seeds in Mexico being the highest in the world. A thousand seeds of maize are traded at US \$2.7, compared to US \$1.3 in the United States maize band [33]. For the government, the original seed is produced by the National Institute of Forestry, Agriculture and Livestock Research Postgraduate College, Autonomous Chapingo University, Antonio Narro University and the International Centre for Maize and Wheat Improvement (CIMMYT). The private, public and social sectors are responsible for multiplying, distributing and selling it.

The supply of improved maize seeds in Mexico in the period 2009-2010 was 62.55 thousand tons. Likewise, the average total quantity demanded of seed in the same period was 160.22 thousand tons per year. Of this figure, 68.17 thousand tons corresponded to improved seed and 92.05 thousand tons to creole seed [34]. Seed production is concentrated in the Northwest and Bajio states. Therefore, it is not a coincidence that Jalisco, Michoacán, Sinaloa, Guerrero and Guanajuato are among the states with the highest consumption of improved seed, states where the area sown with this type of input is greater than $70 \%$ [1]. In contrast, the states with strong rooting of native seeds for planting are Oaxaca, Chiapas, Mexico and Puebla.

However, to improve the productivity of the maize sector, the adoption of improved seeds should be part of the adoption of a technological package [35]. Young farmers are more likely to adopt a new technology because they have had more schooling, they accept changes more quickly and consequently the risks [13]. In contrast, older farmers distrust agricultural practices that are different from those traditionally applied in the past [36]. Feder et al. [27] mention that the size of the family plays an important role in the provision of labour. The adoption of new varieties requires more labour inputs and it is assumed that large families provide the labour required to improve maize production practices. Another important factor is the information media used by farmers since they depend on knowing the benefits of technological innovations and decide to adopt [37]. In addition, having a better income is positively associated with the adoption of technologies [38].

Alcon et al. [39] mention that the adoption of technological innovation has been developed along two different lines to explain why some farmers adopt and why others do not. One route uses discrete choice models at the individual level, while the other uses aggregate models that describe the process of adopting a technology and its possible future evolution. The most common approach to explain this categorical variable has been the use of logit or probit models. An extension of this approach is to consider the question of when people adopt and, therefore, allow consideration of the distinction between first and last adopters and the impact of variables that change over time. In these works, the adoption of technology is presented as a dynamic process where farmers learn about technology over time and adopt when the expected benefits of doing so are positive. These works generally explain the time that it takes for an individual to become a potential adopter until adoption takes place by analysing the duration.

\section{Materials and Methods}

\subsection{Study Area}

Maize is the most dominant crop of Southern Mexico, where the highest rates of extreme poverty and subsistence agriculture are concentrated [40]. The state of Chiapas is located in the south-eastern tip of the country bordering Guatemala; it has an area of over 70,000 square kilometres and has the highest poverty, extreme poverty and marginalization rates. The percentage of the population in poverty is $76.2 \%$, which is equivalent to 3.961 million people in this condition [41] (Figure 1). 


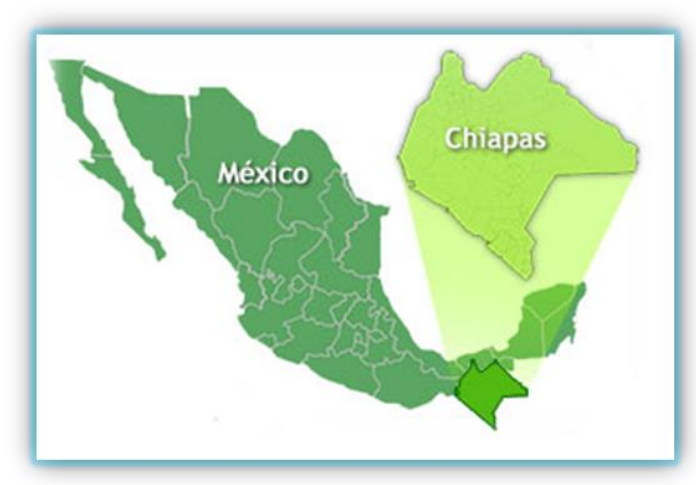

Figure 1. State of Chiapas location. (Source of the image: [42]).

Farming represents $8 \%$ of the gross domestic product of Chiapas and generates employment for $40 \%$ of its economically active population [43]. This region generates great surpluses of maize, which are destined for other parts of Mexico but is still dominated by small-scale farmers who produce for the market and for self-consumption. Nowadays 696,000 hectares of maize are planted, out of which only 240,629 hectares are sown with improved seeds [1]. The average yield is 1.6 tha $^{-1}$ and traditionally, this crop constitutes the diet of the inhabitants. Its planting is linked with a number of cultural, socio-political and economic phenomena since it entails food security and employment for three out of five farmers of its land [44].

In the state of Chiapas, the Frailesca region is the biggest maize-producing region [45]. Within the Frailesca region, the municipalities of Villa Corzo, Villaflores, La Concordia and Chiapas de Corzo stand out.

The territory of Frailesca represents $10.7 \%$ of the state surface, making it the second largest region of the state. The region has climates of warm and semi-warm groups, with abundant rainfall in summer. During the months of May to October, the average minimum temperature ranges between $12{ }^{\circ} \mathrm{C}$ and up to $21^{\circ} \mathrm{C}$. In this same period, the average maximum temperature varies between $21^{\circ} \mathrm{C}$ and up to $34.5^{\circ} \mathrm{C}$. The precipitations in these months range between $1000 \mathrm{~mm}$ and $2600 \mathrm{~mm}$ [45].

In the Frailesca, three types of land can be distinguished, classified by their physiographic position. All the lands located on the margins of the rivers are known as vegas or shallows, which represent $10 \%$ of the total area. Another type of land are the terraces, which have a slope between $5 \%$ and $20 \%$ and represent $56 \%$ of the surface. The third type of land is located on slopes, which have slopes greater than $20 \%$ and occupy $34 \%$ of the surface [45].

\subsection{Definition of Sample Size}

Data were collected from a face-to-face survey with a sample of 200 farmers that was carried out in January and March of 2015; the sample was stratified by seed variety (creole and improved), region (post district), farm size and farmer age. Additionally, the interviews were made in a zone of potential maize production in the state of Chiapas: the towns of Villaflores, Chiapa de Corzo, Villacorzo and La Concordia (Production $>54,000$ tons a year [46]. In order to determine the sample size, information was used regarding the farmers who were registered in the Programa de Apoyos Directos al Campo (PROCAMPO) (A program that promotes and finances agriculture activities in the regions of this study) a program intended to promote and finance agriculture in the counties above-mentioned. Notably, farmers enrolled in this program represent $98 \%$ of total maize farmers [1]. The total population of farmers enrolled in PROCAMPO was 10,800. The sample size was calculated as finite populations with $95 \%$ as the significance level NS and error of $6.87 \%$. The methodological focus followed in this study is better explained in the following scheme (Figure 2). 


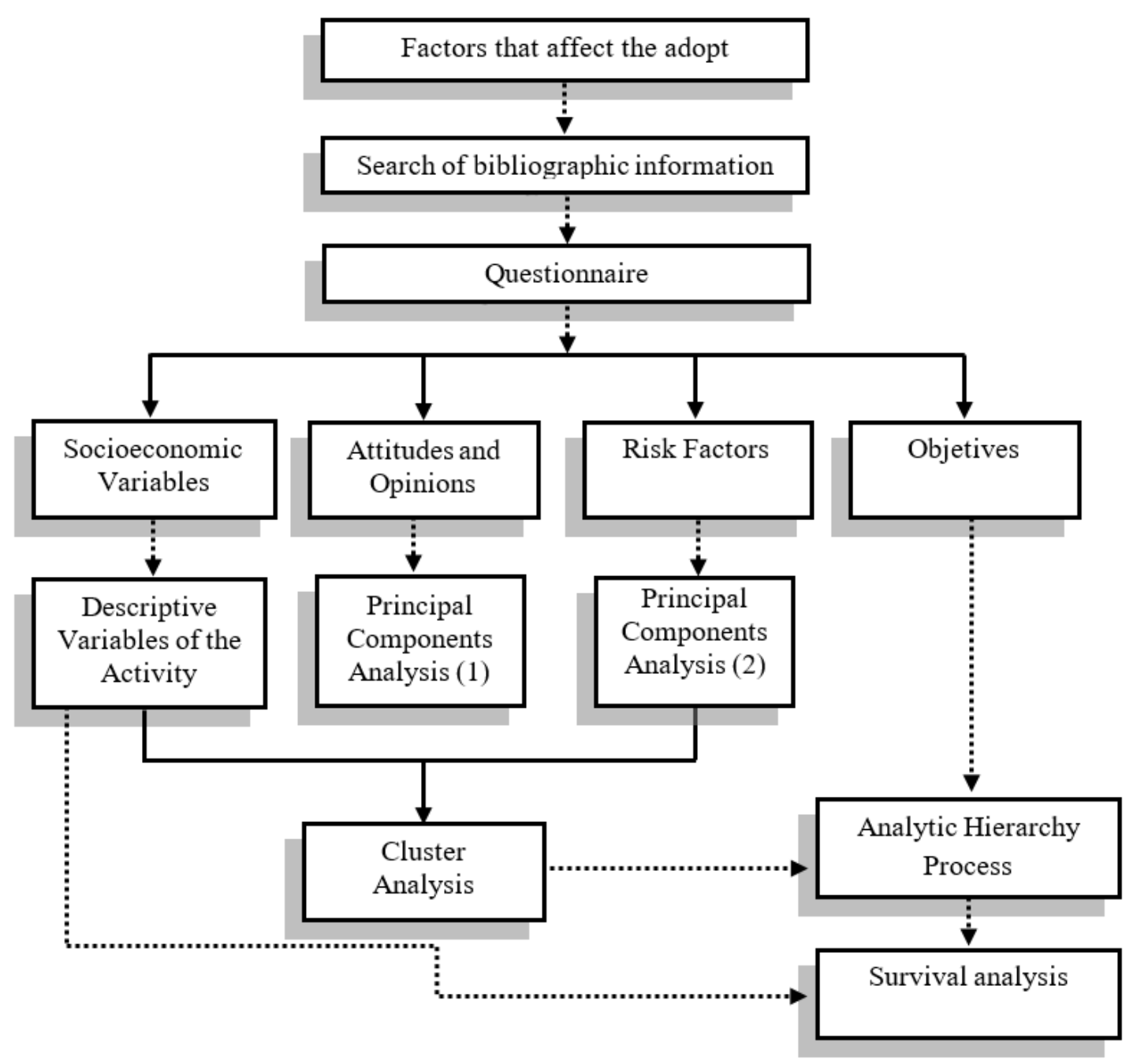

Figure 2. Methodological research scheme.

\subsection{Methodological Framework}

In comparison to the traditional models such as logit, probit and tobit, survival analysis is like Tobit usable for heterogeneous populations with incomplete observations (censored) [11]. However, while Tobit model assumes a normal distribution of the dependent variable, the survival analysis allows for models that do not need any assumption of the underlying baseline distribution of the time-to-event data that tends to violate the normality assumption. It further allows the incorporation of external fixed and time dependent factors and to provide the time of adoption and what are the factors that influence this decision. The Duration Analysis (DA) is able to analyse the changes in the explanatory factors both across farmers and time, thus dealing with both the decision and diffusion of the improved seed adoption. The DA allows for the inclusion of cross-sectional and time-variant data jointly in a dynamic framework [47]. The first application in economics was conducted by Lancaster [17], who analysed the duration of unemployment. In the agriculture sector, survival analysis has been applied in several studies such as the adoption of conservation tillage [18], improved seed [19-23], sustainable technology adoption [24], greenhouses [25], organic agriculture [26], adoption of cross-bred cows [16], adoption of fertilizer and herbicide [27] and drip irrigation [28].

In this paper, we investigated why farmers adopted improved seed but also the timing of the adoption and the time-varying exogenous factors that influenced their decision. The DA was selected because of its capacity to better answer our main research questions and because of our data and sample characteristics (heterogeneous population, censored time variable with violated assumption 
of normal distribution and the presence of relevant exogenous variable related to agricultural policy reforms that may affect the time of adoption).

This statistical method provides us with a methodology and tools that allow for the analysis of the time-event relationship in more flexible conditions.

Let $T$ be a nonnegative random variable that measures the length of a spell (the adoption of improved seed). Additionally, consider $t$ as a realization of $(T)$ where the observed durations of each subject consist of a series of data $\left(t_{1}<t_{2}<\ldots t_{n}\right)$. Let $f(t)$ be a continuous probability distribution function (PDF) of $T$. The probability distribution of the duration variable can be specified by the cumulative density function (CDF) [48,49].

$$
F(t)=\int_{0}^{t} f(s) d s=\operatorname{Pr}(T \leq t)
$$

Equation (1) is the probability of $T$ to be smaller than a value $t$. Nevertheless, researchers are interested in the probability that $T$ has a length of at least $t$. This probability is given by the survival function as:

$$
S(t)=P(T>t)=1-F(t)
$$

The probability that the duration of adoption occurs in an infinitesimal time period $\Delta t$ after time $t$ (given that the non-adoption decision has lasted up to $t$ is:

$$
P(t \leq T<t+\Delta t \mid T>t)
$$

In a further step, the hazard function $h(t)$ is defined as the probability that a farmer adopts the improved seeds at time $t$ (i.e., $T=t$ ), given he has not adopted it before $t$.

$$
h(t)=\lim _{\Delta t \rightarrow 0} \frac{P(t \leq T<t+\Delta t \mid T>t)}{\Delta t}=\frac{f(t)}{S(t)}
$$

The hazard function can be further mathematically expressed as follows,

$$
h(t)=\frac{f(t)}{S(t)}=\frac{d F(t) / d t}{S(t)}=\frac{-d S(t) / d t}{S(t)}=\frac{-d \ln S(t)}{d(t)}
$$

In addition to the length of the duration time of adoption, a set of explanatory variables may affect the distribution of the duration. This means that the $h(t)$ should be respecified and redefined as follows [50]:

$$
h(t, \boldsymbol{x}, \boldsymbol{\theta}, \boldsymbol{\beta})=\lim _{\Delta \rightarrow 0} \frac{\operatorname{Pr}(t \leq T<t+\Delta \mid T \geq t)}{\Delta}
$$

where $\beta$ is a vector of unknown parameters of $x$; the vector of explanatory variables, which may include time-invariant and time-varying variables; and $\theta$ is a vector of parameters that characterize the distribution function of the hazard rate.

After the inclusion of the explanatory variables, the hazard function $h(t, \boldsymbol{x}, \boldsymbol{\theta}, \boldsymbol{\beta})$ can be split into two components. The first component is the part of the hazard that depends on the subject characteristics $g(\boldsymbol{x}, \boldsymbol{\beta})$. The second one is the baseline hazard function $h_{0}(t)$, which is equal to the hazard when all covariates are zero. Notably, the latter one does not depend on individual characteristics; this component captures the way the hazard rate varies in duration. In this context, the shape (distribution function) of the hazard function has important implications for duration dynamics. In our case study, the non-parametric method of the Kaplan-Meier (KM) estimator [51] was used to explore the covariate effects and the potential distribution to be used if the parametric approach was applied. The KM estimator produced an empirical approximation of survival and hazard, which is similar to an exploratory data analysis; denoting the distinct failure times of individuals as $t_{1}<t_{2}<\ldots t_{n}$. 
In our study, the semiparametric Cox proportional hazards model [52] was used to estimate the survival data and explain the effect of explanatory variables on hazard rates. This model was used because of its better fit [48], robustness [53] and no assumptions of any previous distribution and shape of the hazard function. Under the Cox proportional hazards model, the duration of each farmer is assumed to follow its own hazard function $h_{i}(t)$ which can be expressed as:

$$
\begin{gathered}
h_{i}(t)=h\left(t ; x_{i}\right)=h_{0}(t) \exp \left(x_{i}^{\prime} \beta\right)=h_{0}(t) \exp \left(\beta_{1} x_{i 1}+\ldots+\beta_{1} x_{i 1}\right) \text { thus, } \\
\log h_{i}(t)=\alpha(t)+\beta_{1} x_{i 1}+\ldots+\beta_{k} x_{i k}
\end{gathered}
$$

where $\alpha(t)=\log h_{0}(t)$ and $\beta$ are the proportional effects of $\mathrm{x}$ on the probability of improved seed adoption. The estimation procedure is based on the partial likelihood function; more details are available in Cox [52]. The estimation was performed by the R software version 3.3 survival package.

\subsection{Empirical Application}

For the empirical application of the survival analysis, first, the dependent variable that represents the last time to decide to adopt the innovation or the technology was identified. In our case study, the start date was set as the year in which the farmer was responsible for cultivating maize. Additionally, the end period was the year in which the farmer adopted the technology of the improved seeds of maize. For those who had not adopted the technology when the study was conducted, their end year was set as a censored value. Although adoption could take place in the future, for these cases, the statistical procedure of the time variable was censored on the right with the date on which the survey was established as final data.

Regarding the independent variables, according to the literature, the decision of adoption may depend on a broad set of determinant factors that include features of innovation and policy, expectations of farmers, farm structure and the socio-economic environment [54] as well as the behaviours, attitudes and opinions toward innovation and risk. According to the studies reviewed, the most important factors that influence decision making in agriculture are:

(1) Farmer Characteristics (F): gender, education, age, experience and so forth [55,56].

(2) Farm structure (S): location, farm size, production system, irrigation method, labour, machinery, maize varieties used $[39,57,58]$.

(3) Farm Economic data (EC): revenue and production costs, access to credit [59,60].

(4) External factors (E): external factors like media contact, technical assistance, agricultural policies, government programs, access and overtures to universities or research institutions [61].

(5) Farm management and results (M): aspects such as performance and productivity [62,63].

(6) Attitudes and risk perceptions (A): aspects such as resistance to change and interest in technological innovation $[17,59]$.

Attitudes and risk perceptions play an important role as determinants of the adoption of improved seeds $[59,64-66]$ and they were presented in different constructs including various measured items in a Likert scale from zero to 10, where zero indicated that the farmer was not at all in agreement with the claims submitted and 10 was total agreement. Identified affirmations were discussed and analysed in a discussion group formed by various researchers involved in the study. The information contained in the constructs were validated and reduced through the Confirmatory Principal Component Analysis (PCA) following [67]. The variables used are presented in Table 1 with the corresponding reference and the factors resulting from PCA were used as explanatory covariate adoptions of improved maize seeds. 
Table 1. Variables on attitudes and preferences used in the study.

\begin{tabular}{cc}
\hline Attitudinal Variables & References \\
\hline The sale of improved maize prices to cover the higher production costs & {$[68]$} \\
Planting maize with improved seeds can ensure the future of farms & {$[69]$} \\
Seeding with improved maize seeds contributes to a positive image for the exploitation & {$[69]$} \\
Planting improved seeds with increased household income & {$[70]$} \\
Improved maize seeds have better market acceptance & {$[70]$} \\
The masa-tortilla relationship is greater with the improved seeds & {$[71]$} \\
\hline Risk Variables & References \\
\hline Risk from marketing is less with improved seeds & {$[72]$} \\
The risks from proliferation of pests and diseases are lower with improved seeds & {$[60,73]$} \\
There is less risk for lending to farmers with improved seeds & {$[60,73]$} \\
The risk from fluctuation is lower yields improved seeds & {$[74,75]$} \\
The risk from drought is less with improved seeds & {$[75-77]$} \\
The risk of losses due to frost is less with improved seeds & {$[75,76]$} \\
\hline
\end{tabular}

We also included a dummy variable representing the impact of agricultural reform, specifically, the Free Trade Agreement with North America (NAFTA). Trade liberalization was launched in 1994, reinforcing the role of transnational agribusiness that supported the dissemination of technological packages, improved seeds and herbicides and chemical fertilizers through subsidies or production campaigns [35]. Accordingly, the variable had a value of one if the farmer adopted improved seeds after the entry into NAFTA and zero otherwise. Furthermore, economic liberalization formally began when Mexico signed the General Agreement on Custom Duties and Trade (GATT) in 1986. Mexico also went through various internal reforms. From the mid-thirties to early nineties, the Mexican grain sector was supported by the Government through the National Company of Popular Subsistence (Conasupo). In 1999, this company was shut down and government involvement in the sector was reduced to the retail sale of grain through the DICONSA network, the allocation of imports of maize and the Kilo for Kilo program. The Kilo for Kilo program was a tool for technological induction, for producers to use improved seeds. Payments by the Rural Support Program (PROCAMPO) were introduced in 1994 and consists in transferring direct income to farmers who produce basic crops including maize. Transfers are made per hectare and are independent of productivity. Since 1991, the controlled Support to Commercialization program (ASERCA) has provided support for the commercialization of some basic crops in regions with surpluses. The Rural Alliance program was created in 1995 with the main objective to increase agricultural productivity and provide farmers with funds for investment and health projects. In short, PROCAMPO, ASERCA and the Rural Alliance were created as transition policies so that producers would face foreign competition and to transform the structure of agricultural production in Mexico [78].

\section{Results}

\subsection{Descriptive Analysis of Hypothetical Variables}

The confirmatory ACP results indicate that a single factor (potential acceptance of improved maize seeds) explains $68 \%$ of the variability in the original variables, with accepted goodness of fit measures. Similarly, another factor regarding risk aversion behaviour was estimated with $56 \%$ of variability explanation (Table 2). 
Table 2. Confirmatory results of the Principal Component Analysis (PCA) on farmers' attitudes and risk behaviour.

\begin{tabular}{cc}
\hline Variables & $\begin{array}{c}\text { Confirmatory Factor: } \\
\text { Potential Acceptance of Improved Maize Seeds }\end{array}$ \\
\hline The sale of improved maize prices to cover the higher production costs & 0.85 \\
\hline Planting maize with improved seeds can ensure the future of farms & 0.84 \\
\hline $\begin{array}{c}\text { Seeding with improved maize seeds contributes to a positive image for } \\
\text { the exploitation }\end{array}$ & 0.83 \\
\hline Planting improved seeds with increased household income & 0.82 \\
\hline Improved maize seeds have better market acceptance & 0.81 \\
\hline The masa-tortilla relationship is greater with the improved seeds & 0.77 \\
\hline Cronbach' Alfa: 0.882, KMO: 0.839, Bartrlet Test: 774.32 (0.000, explained variance: $68 \%$, rotation method: Varimax \\
\hline Risk from marketing is less with improved seeds & Risk Aversion \\
\hline improved seeds & 0.87 \\
\hline The risks from proliferation of pests and diseases are lower with & 0.82 \\
\hline There is less risk for lending to farmers with improved seeds & 0.81 \\
\hline The risk from fluctuation is lower yields improved seeds & 0.79 \\
\hline The risk from drought is less with improved seeds & 0.78 \\
\hline The risk of losses due to frost is less with improved seeds & 0.21 \\
\hline Cronbach' Alpha: 0.795, KMO: 0.767, Bartrlet Test: 613.85 (0.000), explained variance: $56 \%$, rotation method: Varimax \\
\hline
\end{tabular}

Both factors were used to segment farmers according to their attitudes towards improved seeds and risk perception. In both cases, the results showed the presence of three clearly differentiated clusters: (1) In transition: neutral attitude toward the improved seeds $(n=105),(2)$ Conservative: negative attitude towards the improved seeds $(n=37)$ and (3) Innovative: positive attitude towards the improved seeds $(n=58)$. Regarding the attitudes towards risk, the segments were: risk averse, risk neutral and risk loving. Using the AHP methodology, we also identified the main objectives that farmers used as a reference to guide its operation. Notably, the economic objectives were the most important $(63.50 \%, 51.16 \%$ and $48.46 \%$ for farmers in transition, conservative and innovative categories, respectively), followed by environmental $(22.32 \%, 27.75 \%, 38.88 \%)$ and socio-cultural objectives $(14.18 \%, 21.09 \%, 12.67 \%)$. Importantly, farmers in transition had an increased interest in the economic objectives, while the conservatives had an increased interest in the socio-cultural and the innovators in the environmental objectives.

Table 3 shows the descriptive statistics of the main variables that influence the time of adoption of improved seed maize by farmers. The table showed that of the 200 farmers, $20 \%$ were censored (non-adopters) and the rest (80\%) were adopters of improved seeds at the time of conducting the survey. Farmers who adopted had an average age of 51 years old; had three family members and a higher education. They were farmers who had attended courses on technology; they also had about five hectares of land cultivated with a yield of $4 \mathrm{Tn} \cdot \mathrm{ha}^{-1}$. Comparatively, the censored farmers were older (75 years old), with six family members and were illiterate, had basic education, or secondary education. Additionally, they did not attend courses on technology. These were farmers with an area of two hectares of arable land and their yield was $2 \mathrm{Tn} \cdot \mathrm{ha}^{-1}$. 
Table 3. Description of the variables used in the survival model statistical analysis $(n=200)$.

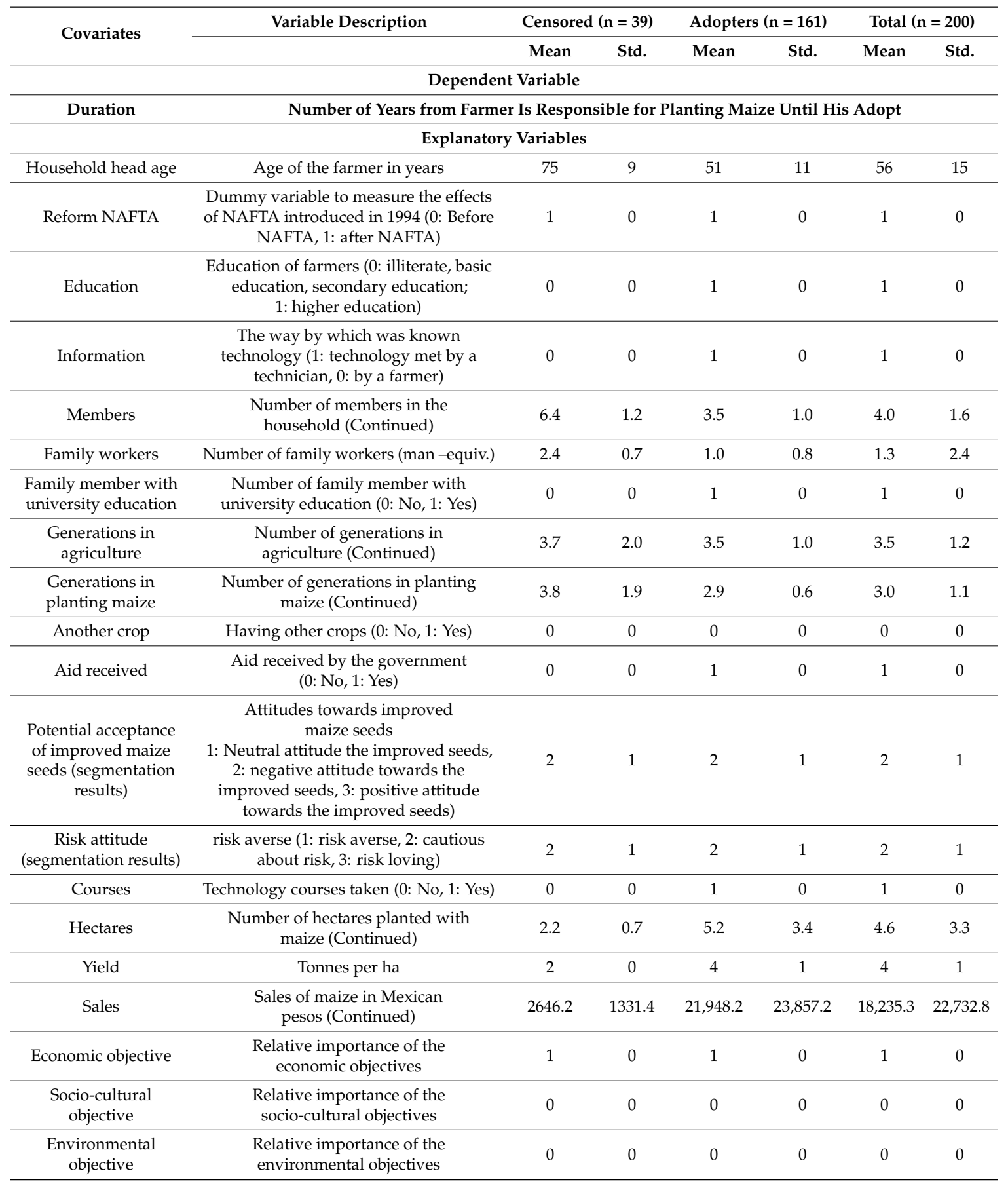

It is important to mention that two analyses were performed: First, a non-parametric (Kaplan-Meier) analysis where each variable was analysed separately to analyse whether the curves were equal or not. In cases where the survival curves estimated for each group were markedly different, the estimator of the cumulative risk function was calculated for each group, with which it could be observed that the group had a higher risk of failure as time elapsed. Finally, in the case where the survival curves and the accumulated risk showed a difference in the treatments, then this fact was corroborated with the log-rank test. Second, all variables that influenced the occurrence of the fault event (preliminary analysis) were used for a semi-parametric analysis (Cox Model), which showed the variables that fulfilled the assumptions that the Cox model calls for and are significant. 


\subsection{Econometric Analysis}

The non-parametric analysis of the adoption periods considers the nature of the censored data and is carried out through an estimated survival function according to Kaplan-Meier (KM). This information allowed us to suggest appropriate functional forms for parametric analysis in case they needed to be performed [79]. In addition, it helped represent the speed of adoption of the improved seeds in different farmer groups. The KM method was used in our case study to summarize the length of time before farmers adopted improved maize seeds. Figure 3 is used to describe the adoption-spell, which is the difference between the first year when the farmer is responsible for planting maize and the first year of the adoption of improved maize seeds. The horizontal axis shows the number of years that elapsed since the first year as responsible for planting maize until the first adoption of improved seed and the vertical axis shows the respective probabilities.

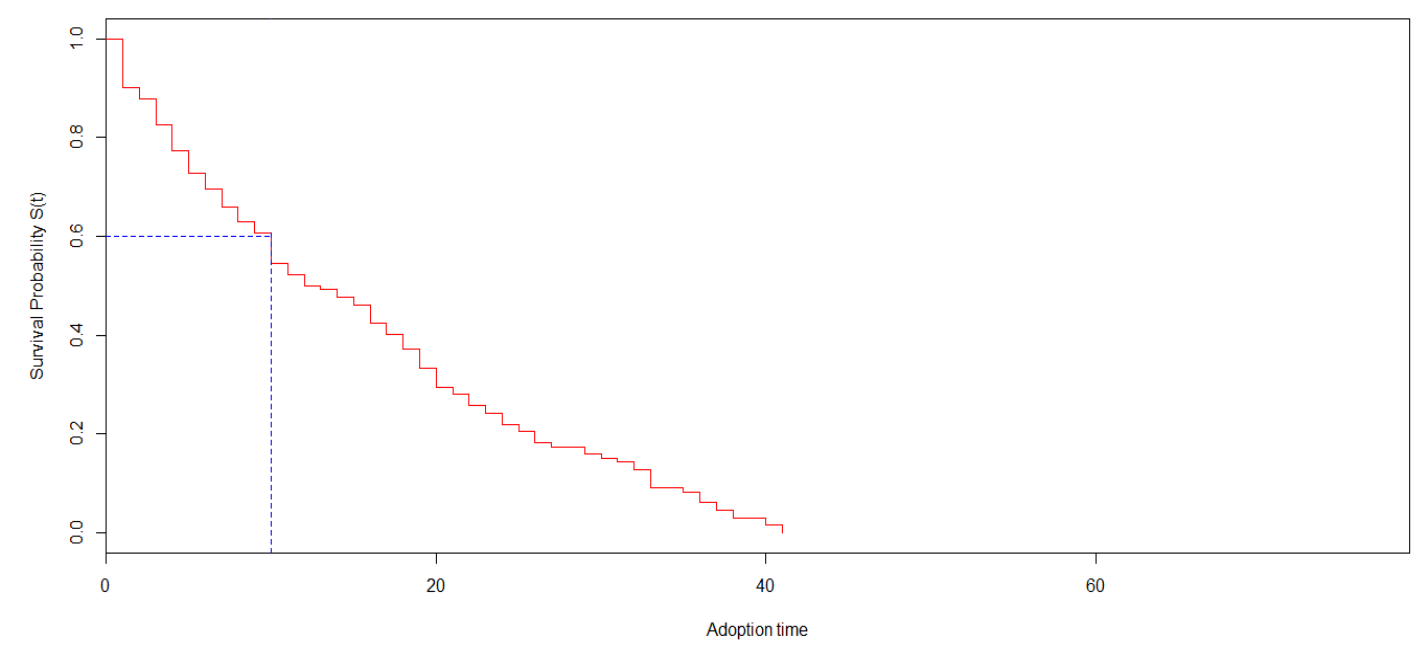

Figure 3. Kaplan-Meier survival estimate.

The curve shows that $60 \%$ of farmers using improved seeds adopted their use within 10 years after they were responsible for planting. Approximately $80 \%$ of farmers changed to improved seed in the first 25 years, as shown in Figure 4.

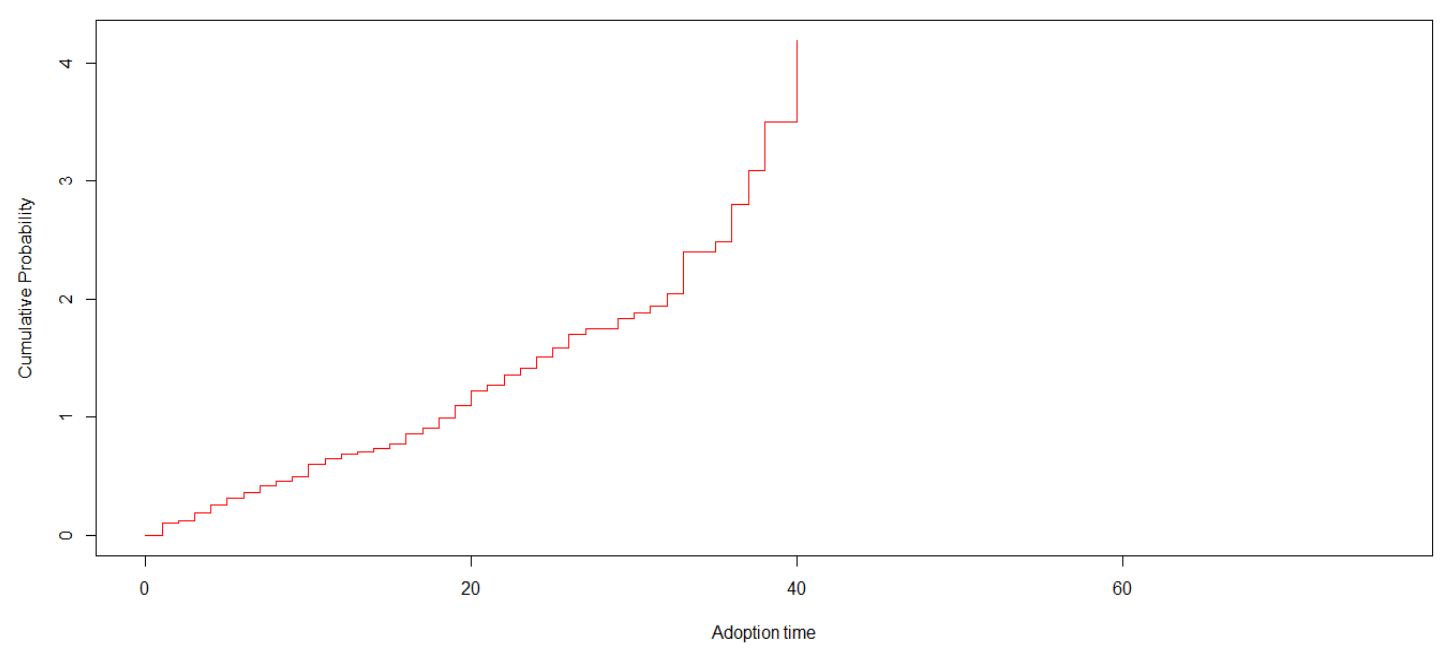

Figure 4. Cumulative adoption.

The above statements were confirmed by the function of cumulative risk (Figure 4), showing that there was a slow adoption in the early years. Mexican farmers showed a moderate trend over time for change, which is due to an attitude of distrust of different agricultural practices from those 
traditionally held. The farmer does not immediately adopt the improved seeds, instead preferring to wait for someone else to do it first. Based on this experience, potential users decide whether or not to use it, as also mentioned by Rivera and Romero [36]. These results are in contrast with those provided by Bekele and Abebe [55] in Ethiopia, where 50\% of farmers adopted hybrid maize during the two first years after the first exposure, then the rate of adoption dropped. Furthermore, in the case of the adoption of new wheat varieties in Pakistan, farmers adopted within the first six years [80].

The quality of the information that farmers have about agricultural technologies may affect their decision to adopt. Figure 5 relates to the quality of information and the adoption rate of our sample. Results showed that farmers who received information from a qualified institution or individual (agricultural technician) agreed to adopt improved seeds, while only $40 \%$ (28 of 68) receiving information from another source (employees, family, another farmer, media, consumers and wholesalers) decided to change. Our results were in agreement with what Rogers [81] noted about the quality and reliability of information in potential adopters increasing the likelihood of adoption.

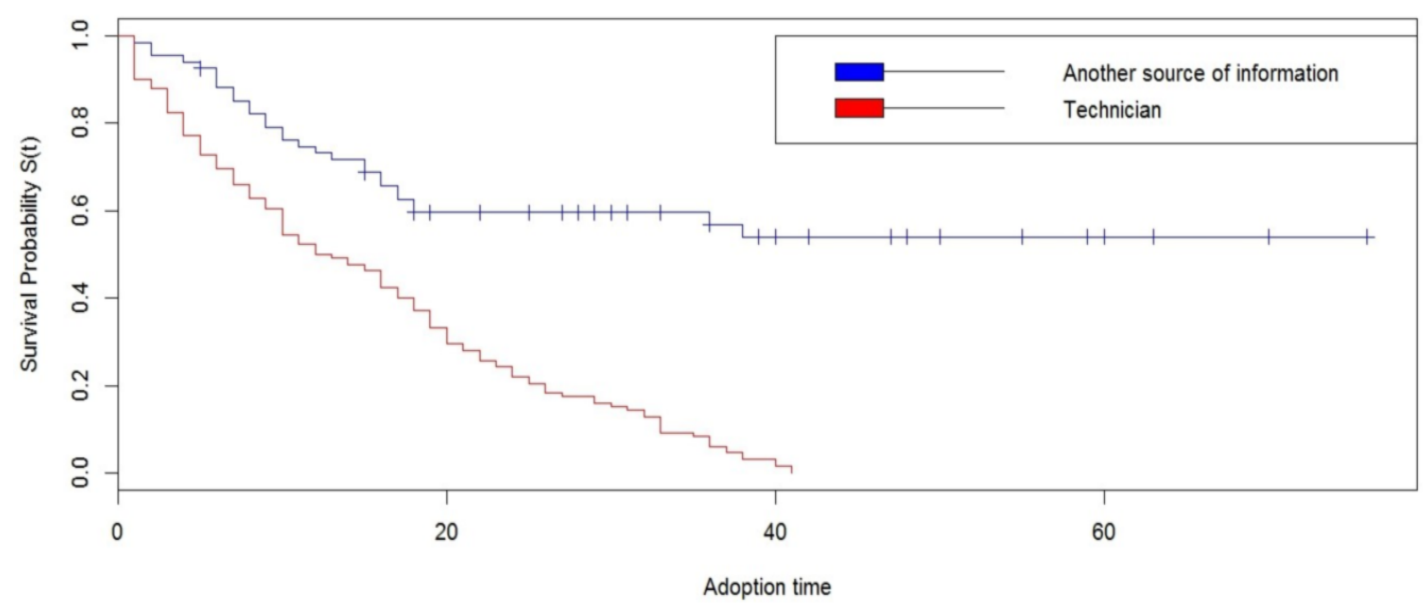

Figure 5. Kaplan-Meier survival curve by information received on the technology.

Results of the KM estimator for the different regions analysed are presented in Figure 6. The results showed some level of heterogeneity among areas, for example, in the first twenty years, farmers in the region with the highest adoption rate were from Chiapas de Corzo, while the region of Villaflores exhibited the lowest adoption rate. These results were in agreement with the fact that Chiapas de Corzo is strategic, as it is located $15 \mathrm{~km}$ from the centre of Tuxtla Gutierrez (the State capital) with better communication networks for the logistics of harvesting, marketing and access to better information.

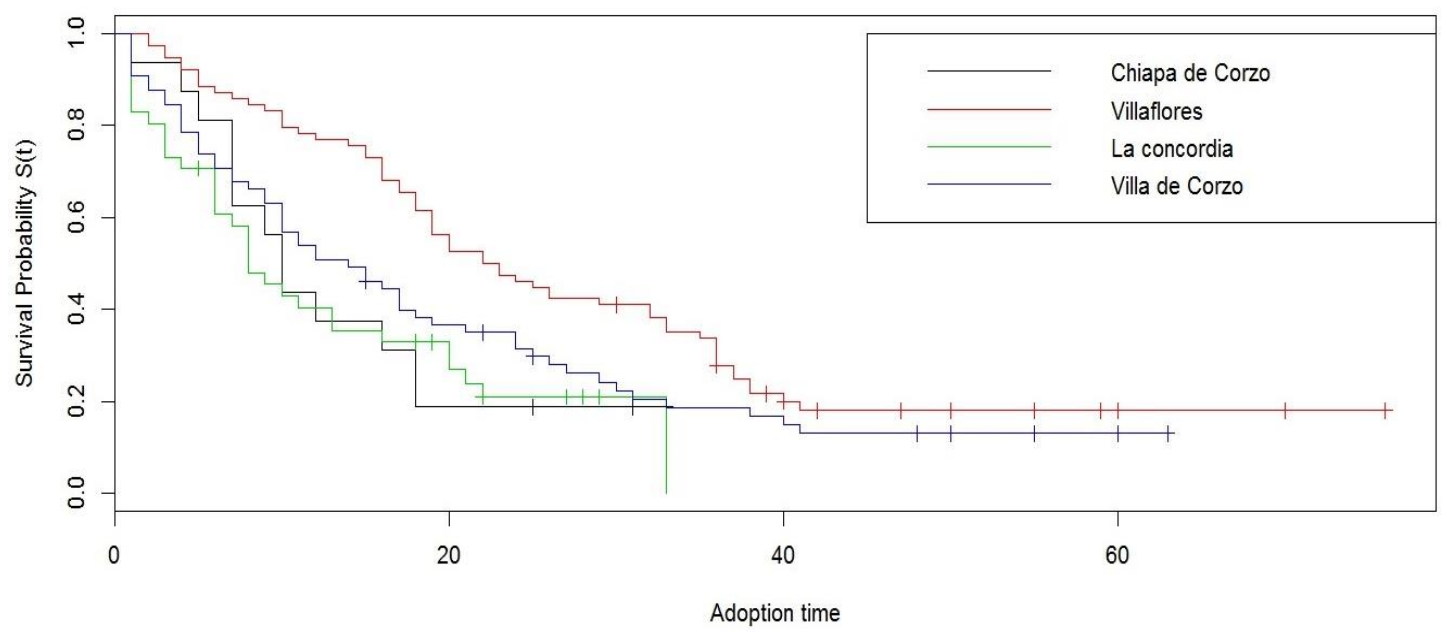

Figure 6. KM survival estimate by towns. 
These results affirm the findings of Abdulai and Huffman [82], whose studies found a negative and significant association between the distance of the market (big city) and the adoption of new agricultural technologies. In this context, previous studies have mentioned that the distance from the farm to the market may affect the adoption of agricultural technologies, especially in developing countries where communication networks are underdeveloped [83]. Additionally, Rogers [84] emphasized that those farmers living near the cities had higher adoption rates. Furthermore, they noted that this behaviour was attributed to reduced transport costs and to the higher possibility of easily contacting new extension workers and other farmers.

Figure 7 explains the Kaplan-Meier estimator of the survival function disaggregated by attitudes. The results showed some level of heterogeneity; for example, farmers who had a positive attitude towards improved seeds tended to adopt them more quickly. The results also suggested that farmers with positive attitudes and opinions toward improved seed maize had a shorter duration. Parra and Calatrava [85] also found that positive attitudes positively influenced the decision to adopt.

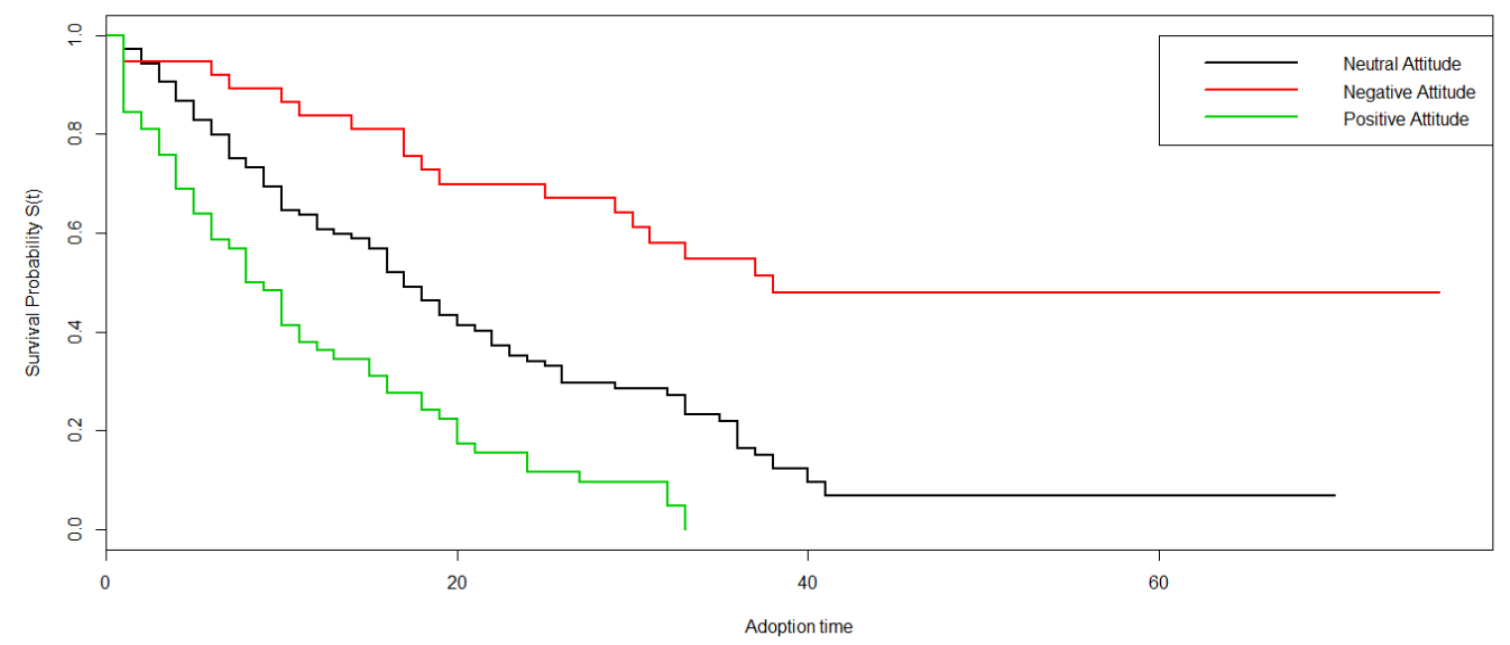

Figure 7. KM survival estimate by attitudes towards improved seeds.

Figure 8 shows that farmers who were more cautious in managing water resource for irrigation had a faster adoption rate. The farmer's perception of risk and their attitude towards the improved seeds played a decisive role in the decision-making process of adoption. The literature reports that the uncertainty generated in farmers is associated with the perceived risks in several areas. On the one hand, there is the availability of physical and financial resources that count; and on the other, the aspects of expected profitability with the use of the new technology in addition to the risk and uncertainty of grain prices in the market and the personal characteristics of the farmer in terms of their partial or total disposition to change [86].

Regarding the availability of physical and financial resources, the total area reflecting household wealth is an indicator of the farmer's ability to take greater risks and be willing to use improved maize seeds [87].

To estimate the risk and survival functions that consider the effect of different independent variables, we used the semi-parametric proportional risk model from Cox [52] because it does not impose any restrictions on how the baseline risk function should be and also because it performed better with our dataset. The model was estimated using the different covariates available in our questionnaire (see Table 3 for more details). We followed the forward method to determine the final list of variables included in the model. At a 95\% confidence level, we rejected the null hypothesis that all coefficients were jointly equal to zero. Our estimated model (Table 4 ) explained $76.2 \%$ of the variation in survival times by the covariates. 


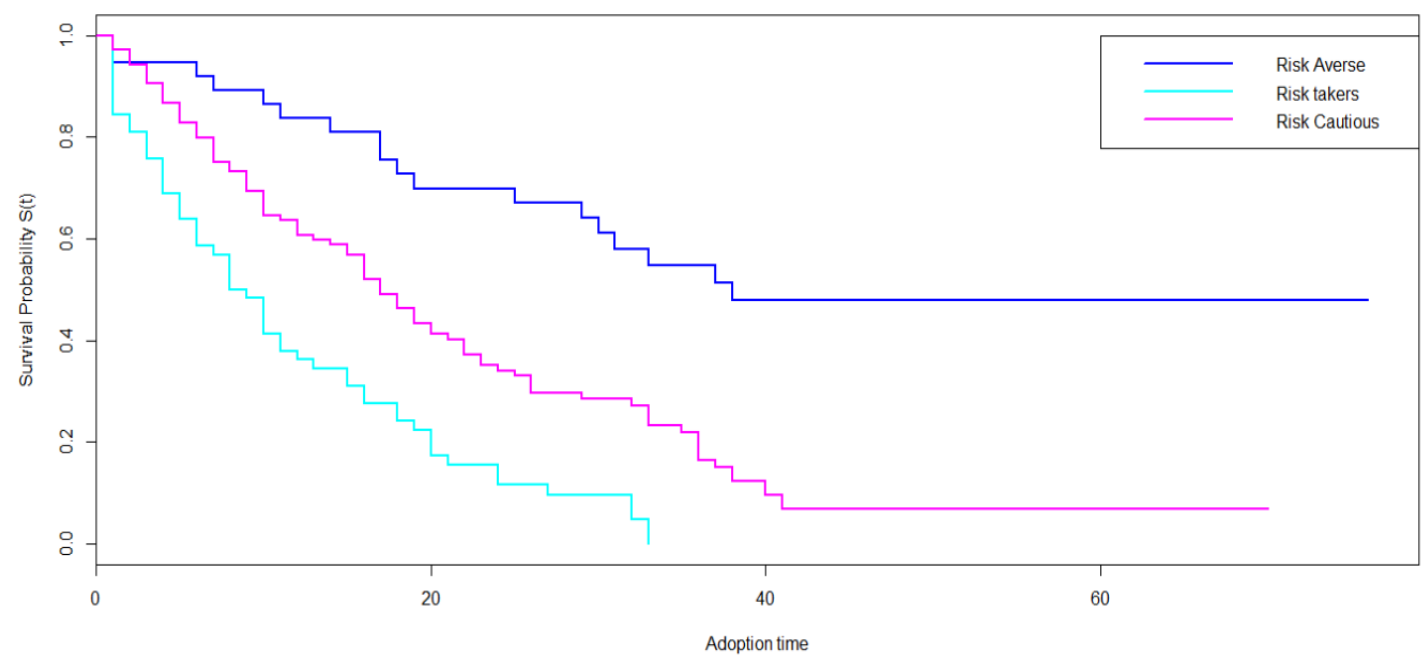

Figure 8. KM survival estimate by perceptions of risk.

Table 4. Results of the Cox proportional model for the adoption of improved seeds.

\begin{tabular}{cccc}
\hline Variables & $\boldsymbol{\beta}$ & e ( $\beta$ ) & $p$ Value \\
\hline Household head age & -1.22 & 0.29 & $0.000^{* * *}$ \\
Number of generations in agriculture & 0.22 & 1.25 & $0.050^{* *}$ \\
NAFTA reform (year 1994) & -1.86 & 0.15 & $0.000^{* * *}$ \\
Number of family workers & -0.37 & 0.68 & $0.000^{* * *}$ \\
Courses for best farming practices & 1.65 & 5.25 & $0.000^{* * *}$ \\
PCA: Perception factor for accepting improved seeds & 0.44 & 1.55 & $0.001^{* *}$ \\
PCA: Risk behaviour (risk lover) & 0.45 & 1.57 & $0.010^{*}$ \\
Pseudo R2 & 0.76 & & \\
Likelihood ratio test & 286.8 & & \\
Wald & 187.1 & & \\
Score (logrank) test & 254.3 & & \\
\hline
\end{tabular}

Significance levels: ${ }^{* * *} p<0.001 ;{ }^{* *} p<0.01,{ }^{*} p<0.05$.

Results indicated that seven covariates were better associated with the adoption rate of improved seeds among maize farmers in the area of study. As expected, young farmers tended to easily adopt the improved seeds; this is in line with the literature where $[27,88,89]$ found that older farmers tended to prefer their traditional agricultural practices. Furthermore, young people were associated with higher risk-taking behaviour than the elderly, as shown by Simtowe et al. [90]. Our results also showed that the increase in the number of generations working in agriculture also increased the adoption of improved seed. In this context, farmers who had extensive experience from previous generations were able to better evaluate information about agricultural technology and better appreciate the advantages offered to them [91].

The dummy variable representing policy changes of the reforms undertaken by NAFTA in 1994 was also significant and negatively associated with the decision to adopt the improved seeds. That is, with the introduction of NAFTA in Mexico, the rate of adoption of improved seeds significantly decreased. This result can be explained by the fact that the policy reform led to an increase in the price of the improved seeds, which negatively affected the production costs for both farmer groups, that is, the farmers who had already cultivated the improved seeds and those likely to adopt them. An increase in the production costs resulting from policy changes might negatively affect the adoption rate of technology [78]. These findings coincide with Nadal and Wise [92], who analysed the NAFTA impact and mentioned that farmers continued planting their own seed. Moreover, Nadal [93] highlighted that NAFTA affected the credit support and infrastructure of farmers, which sheds light on the low rate of adoption after the policy reform. 
In the same way, our results showed that the adoption of improved seeds was affected by the number of family members working in the maize production process. The higher the number of family members, the lower the adoption rate. Farmers with the largest number of families involved in growing maize had fewer resources to invest since most of the resources were estimated to self-substance and maintenance obligations [89]. Due to budget constraints resulting from the high level of family expenditure (the number of family members of creole farmers was higher), the farmers were restricted in the choices they made on which technology was employed, the degree of innovation and their choice of crops [27]. Our results showed that creole household farmers had six family members, in contrast to the adopter farmers (three family members). These results help to understand that they are forced to select and save the best seed from a previous production season for their use in the following year; in contrast to what happens with improved seed, which must be purchased each year to ensure expected returns. This previous result was in agreement with what Di Falco and Bulte [94] found regarding the negative impact of family members on adoption rate. The authors mentioned that the number of families involved in production could negatively interact with the speed of technology adoption. Mafuru et al. [95] also found that the probability of adoption of maize technology in Tazmania reduced by $1.9 \%$ for an increase in one unit of family labour. However, the literature also reflects some contrary results as in the case of Noltze et al. [96], who indicated that large families provide the labour required for maize production practices and this may increase the adoption rate of improved seeds.

Results showed that the courses farmers received and the extension contacts on the best farming practices had a positive impact on the adoption rate. The continuous contact a farmer has with extension agents makes them aware of new technologies and how to apply them. Farmer perception towards innovation largely depends on their knowledge and information level and may increase their adoption rate. Farmers' knowledge on improved agricultural technology can be accelerated with the help of extension agents and farm information sources [88,97]. Likewise, other studies deem farmer objectives as relevant factors in explaining the decision to convert [98]; however, in our case study, this variable was not statistically significant. When analysing farmer perception towards the improved seeds using a confirmatory Principal Component Analysis (CPA), the results showed that the probability of adoption increased when perception was positive. Those who believed in the impact of the improved seeds in increasing their household income with better market acceptance of their products and higher productivity were more likely to adopt, that is, had a higher hazard to convert. This finding was in agreement with what Parra and Calatrava [85] found regarding positive attitudes positively influencing the decision to adopt. Becerril and Abduali [99] mentioned that the adoption of improved maize varieties helped increase the household per capita income by 136-173 Mexican pesos, as an average; thereby reducing their probability of falling below the poverty line by roughly $19-31 \%$.

Regarding the farmers risk behaviour variable, the results of the confirmatory PCA showed that farmers that exhibited risk-loving behaviour were more likely to adopt technological innovations. These results were similar to those obtained by Brick and Visser [100], who showed that farmers who were risk averse were less likely to use modern agricultural inputs. This result was also in agreement with Albert and Duffy [101], who found that risk aversion increased with age and decreased with increasing cognitive ability [102]. Figure 9 shows the conditional probability that farmers adopt improved maize seeds in different periods of time with respect to the possible values of the explanatory covariates included in our model (Table 4). Taking into account the estimated survival time by regressing the proportional risk of Cox, the probability that a farmer will adopt before twenty years was $50 \%$. 


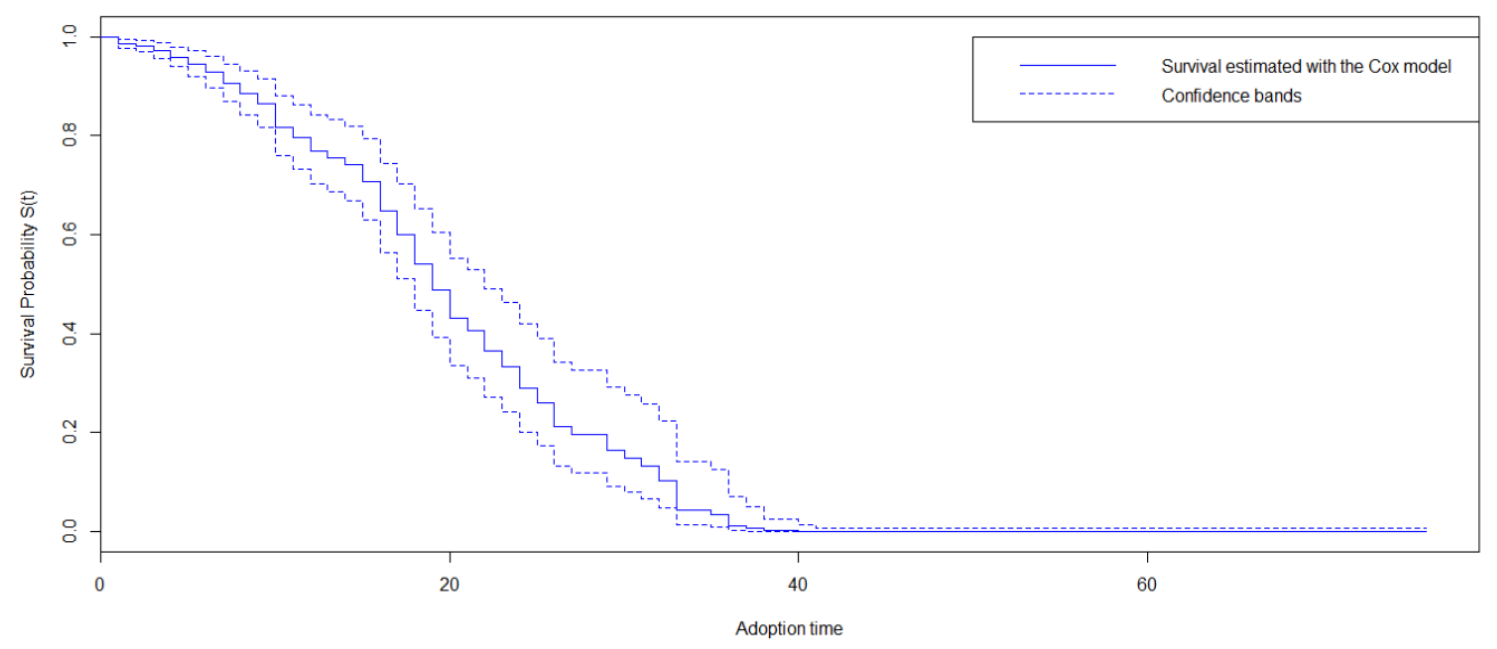

Figure 9. Cox model survival estimate.

\section{Conclusions}

This study focused on the evaluation of the determinant factors affecting the adoption rate of improved maize seeds as well as the time of the conversion decision in Chiapas (Mexico), using the survival analysis model. The dependent variable represented the year in which the farmer was responsible for planting maize until the time of the adoption. The explanatory variables considered were the characteristics of the farmer and the farm, farm management, exogenous factors and attitudes and risk behaviours. We used the Principal Component Analysis (PCA) to reduce the information regarding the perception and risk behaviour. Our results showed that $60 \%$ of farmers adopted the improved seeds within the first 10 years after they were responsible for the farm. Additionally, the results showed that this adoption rate also varied by location. Therefore, agricultural development strategies should address the different categories of farmers and locations to promote successful and improved seed maize adoption in the various locations.

These results provide the basis for better informed policy interventions in rural areas where an increase in the productivity of maize is required. Given the importance of the crop in the state of Chiapas, there is significant interest in understanding the determinant factors for the adoption of the improved seeds. Our study confirmed that young farmers with low numbers of family members and high numbers of generations, who were also dedicated to agriculture, had sufficient information about innovation and were willing to take risks, were more likely to adopt improved seeds. Our results also revealed the incapacity of the agricultural reform of NAFTA in 1994 to ensure sustainable economic growth. This reform decreased the rate of adoption of improved seeds, which could be because the non-adopter farmers suffered from an increase in production costs. Furthermore, small producers of maize during the transition period of NAFTA reforms were exposed to high levels of market volatility and uncertainty. Accordingly, future trade agreements must be accompanied by policies that protect the most vulnerable strata of the population.

The importance of government support during the production process and market prices may play an important role in mitigating risk perception; this would also be a valid strategy in increasing the adoption rate of technologies. Agricultural reforms must have features that incorporate new programs for the transfer of financial resources, especially those focused on small producers. In light of this, agricultural development strategies should address the various categories of farmers and locations to successfully and efficiently promote the adoption of technological innovation. Additionally, extension efforts should be strengthened to increase the flow of information to farmers. Similarly, courses from qualified agents would increase the likelihood of changes towards the adoption of improved maize seed. 
Policies promoting the adoption of improved seed maize should take into account the nature and factors that determine the adoption rate. The understanding of the dynamics for the adoption may help improve strategies to accelerate adoption. Rural extension should aim to improve the quality of life of the rural population in a sustainable way. The public extension service plays an important role but could be strengthened to provide objective and timely information. Abandoning public breeding programs could, therefore, lead to less technological diversity and higher seed prices, which would have negative implications for agricultural development in general and smallholder farmers in particular. To achieve the above, it is necessary to create joint actions among all the actors involved in the sector. In this way, our study contributes to the development of new research, transference and adoption of future technologies. The adoption of improved seeds together with technological innovations can increase the productivity of maize in non-irrigated lands in Mexico. This will allow to satisfy the national demand and, therefore, contribute to the sustainability of the local economy. The challenge is to increase maize production sustainably without degrading the natural resource base. Producers who choose to continue using creole seeds can direct them to new markets with defined characteristics, which can also improve the production units and the living conditions of the rural population. In all cases, it is worth mentioning that the results should be taken with caution because of the sample characteristics.

Supplementary Materials: The following are available online at http:/ /www.mdpi.com/2071-1050/10/10/3543/ s1, Questionnaire.

Author Contributions: B.I.S.T. and Z.K.C. conceived the study idea, co-wrote the paper and conducted investigation, document collection and analysis; O.P.R. revised of software and analysis; J.M.G. revised the paper.

Funding: This research received no external funding.

Acknowledgments: We thank the Consejo Nacional de Ciencia y Tecnología (CONACYT) and the Instituto Nacional de Investigaciones Forestales, Agrícolas y Pecuarias (INIFAP) for their support in carrying out this research.

Conflicts of Interest: The authors declare no conflict of interest.

\section{References}

1. SIAP. Avances de Siembras y Cosechas por Estado y Año Agrícola; Secretaría de Agricultura, Ganadería, Desarrollo Rural, Pesca y Alimentación: Mexico City, Mexico, 2016. Available online: http:/ / siap.gob.mx (accessed on 25 March 2016).

2. FAOSTAT. Organización de las Naciones Unidas Para la Alimentación y la Agricultura (FAO). 2016. Available online: http:/ / faostat.fao.org (accessed on 9 July 2016).

3. Harrison, P. Agricultura Mundial: Hacia los Años 2015/2030. Dirección de Información de la FAO. 2002. Available online: http:/ / www.fao.org/docrep/004/y3557s/y3557s06.htm (accessed on 20 January 2017).

4. Nelson, C.; Rosegrant, W.; Koo, J.; Robertson, R.; Sulser, T.; Zhu, T.; Ringler, C.; Msangi, S.; Palazzo, A.; Batka, M.; et al. Cambio Climático: El impacto en la Agricultura y los Costos de Adaptación; Política Alimentaria; FAO: Washington, DC, USA, 2009.

5. FAO. Alimentación y Agricultura Sostenible; FAO: Washington, DC, USA, 2017. Available online: www.fao. org/sustainability/es/ (accessed on 13 July 2017).

6. Turrent, A.; Wise, T.; Garvey, E. Mexican Rural Development Research Reports; Wilson Center: Washington, DC, USA, 2012.

7. Schroeder, C.; Onyango, K.; Ranabhat, N.; Jick, N.; Parzies, H.; Gemenet, D. Potentials of hybrid maize varieties for small-holder farmers in Kenya: A review based on swot analysis. Afr. J. Food Agric. Nutr. Dev. 2013, 13. Available online: https:/ / www.ajol.info/index.php/ajfand/article/view/87480 (accessed on 15 April 2016).

8. Luna, B.; Hinojosa, M.; Ayala, O.; Castillo, F.; Mejía, J. Perspectivas de desarrollo de la industria semillera de maíz en México. Rev. Fitotec. Mex. 2012, 35, 1-7.

9. $\quad$ Snics. Catálogo Nacional de Variedades Registradas; SAGARPA: Mexico City, Mexico, 2018. 
10. Rodríguez, R.; Donnet, L.; Jácome, S.; Jolalpa, J.; López, D.; Domínguez, C.; Moctezuma, G.; Espinoza, J.; Cepeda, J.; Rentería, I.; et al. Caracterización de la Demanda de Semillas Mejoradas de Maíz en Tres Agro-Ambientes de Producción de Temporal en México, 1st ed.; Rodrígez, R., Donnet, L., Eds.; Instituto Nacional de Investigaciones Forestales, Agrícolas y Pecuarias: México City, Mexico, 2015; 170p.

11. Beyene, D.; Kassie, M. Speed of adoption of improved maize varieties in Tanzania: An application of duration analysis. Technol. Forecast. Soc. Chang. 2015, 96, 298-307. [CrossRef]

12. López, M.; Filipello, M. Maize seed industries revisited: Emerging roles of the public and private sectors. In Primera Parte de 1993-1994 CIMMYT World Maize Facts and Trends: Maize Seed Industries Maize Seed Industries Revisited: Emerging Roles of the Public and Private Sectors; CIMMYT: Mexico City, Mexico, 1994.

13. CIMMYT. La Adopción de Tecnologías: Guía Para el Diseño de Encuestas; de Economía, C.P., Ed.; CIMMYT: México City, Mexico, 1993; 88p.

14. Ghadim, A.; Pannell, D.; Burton, M.P. Risk, uncertainty, and learning in adoption of a crop innovation. Agric. Econ. 2005, 33, 1-9. [CrossRef]

15. Klein, J.; Moeschberger, M. Survival Analysis of Failure Data; Wiley: New York, NY, USA, 1997.

16. Hattam, C.E.; Lacombe, D.J.; Holloway, G.J. Organic certification, export market access and the impacts of policy: Bayesian estimation of avocado smallholder “times-to-organic certification” in Michoacán Mexico. Agric. Econ. 2012, 43, 441-457. [CrossRef]

17. De Cock, L. Determinants of organic farming conversion. In Proceedings of the XI International Congress of the European Association of Agricultural Economists (No 24675), Copenhagen, Denmark, $24-27$ August 2005; European Association of Agricultural Economists: Uppsala, Sweden, 2015.

18. Sánchez-Toledano, B.; Kallas, Z.; Gil, J. Importancia de los objetivos sociales, ambientales y económicos de los agricultores en la adopción de maíz mejorado en Chiapas. Rev. Fac. Cienc. Agrar. Univ. Nac. Cuyo 2017, 49, 269-287.

19. Herrera, E.; Macías, A.; Díaz, R.; Valadez, M.; Delgado, A. Uso de semilla criolla y caracteres de mazorca para la selección de semilla de maíz en México. Rev. Fitotec. Mex. 2002, 25, 17-23.

20. Seré, C.; Estrada, J.E.F. Estudios de adopción e impacto en pasturas tropicales. In Investigación con Pasturas en Fincas CIAT; Centro Internacional de Agricultura Tropical (CIAT): Palmira, Colombia, 1990.

21. Welch, F. Education in production. Ecoonomy 1970, 8, 39-59. [CrossRef]

22. Knowler, D.; Bradshaw, B. Farmers' adoption of conservation agriculture: A review and synthesis of recent research. Food Policy 2007, 32, 25-48. [CrossRef]

23. Rigby, D.; Young, T.; Burton, M. The development of and prospects for organic farming in the UK. Food Policy 2001, 26, 599-613. [CrossRef]

24. Hazell, P.; Wood, S. Divers of change in global agriculture. Philos. Trans. R. Soc. B 2008, 363, 495-515. [CrossRef] [PubMed]

25. Abebaw, D.; Belay, K. Factors influencing adoption of high yielding maize varieties in Southwestern Ethiopia: An application of logit. Q. J. Int. Agric. 2001, 401, 49-167.

26. Hogeland, A. The economics culture of, U.S. agricultural cooperatives. Cult. Agric. 2016, 28, 67-79. [CrossRef]

27. Feder, G.; Just, R.; Zilberman, D. Adoption of agricultural innovations in developing countries: A survey. Econ. Dev. Cult. Chang. 1985, 33, 55-298. [CrossRef]

28. Chilonda, P.; Van Huylenbroeck, G. Attitudes towards and uptake of veterinary services by small-scale cattle farmers in Eastern province Zambia. Outlook Agric. 2001, 30, 218-231. [CrossRef]

29. Córdova, H.; Castellanos, S.; Bolaños, J. Veinticinco años de mejoramiento en los sistemas de maíz en Centroamérica: Logros y estrategias hacia el año 2000. Agron. Mesoam. 2002, 13, 73-84. [CrossRef]

30. Challinor, A.J.; Koehler, A.-K.; Ramirez-Villegas, J.; Whitfield, S.; Das, B. Current warming will reduce yields unless maize breeding and seed systems adapt immediately. Nat. Clim. Chang. 2016, 6, 954-958. [CrossRef]

31. Sánchez-Toledano, B.; Kallas, Z.; Gil, J. Farmer preference for improved corn seeds in Chiapas, Mexico: A choice experiment approach. Span. J. Agric. Res. 2017, 15, e0116. [CrossRef]

32. Cofece. Comisión Federal de Competencia Económica. Empresas Semilleras en México, 2016. Available online: www.cofece.mx (accessed on 25 September 2018).

33. Espinosa, A.; Tadeo, M.; Turrent, A. Concentración de la Oferta de Semillas Mejoradas de Maíz. 2010. Available online: http:/ / www.jornada.unam.mx/2010/03/13/oferta.html (accessed on 25 September 2018).

34. García, J.; Ramírez, R. El mercado de la semilla mejorada de maíz (Zea mays L.) en México: Análisis del saldo comercial por entidad federativa. Rev. Fitotec. Mex. 2014, 37, 69-77. 
35. Fox, J.; Haight, L. La política agrícola mexicana: Metas múltiples e intereses en conflicto. In Subsidios Para la Desigualdad. Las Políticas Públicas del Maíz en México a Partir del Libre Comercio; Dissa Impresores: México City, Mexico, 2010.

36. Rivera, A.; Romero, H. Evaluación del nivel de transferencia y adopción de tecnología en el cultivo de caña de azúcar en Córdoba, Veracruz, México. Av. Investig. Agropecu. 2003, 21, $20-40$.

37. Lee, D. Agricultural Sustainability and Technology Adoption: Issues and Policies for Developing Countries. Am. J. Agric. Econ. 2005, 87, 1325-1334. [CrossRef]

38. Chirwa, E. Adoption of fertiliser and hybrid seeds by smallholder maize farmers in Southern Malawi. Dev. S. Afr. 2005, 22, 1-12. [CrossRef]

39. Alcon, F.; De Miguel, D.; Burton, M. Duration analysis of adoption of drip irrigation technology in southeastern Spain. Technol. Forecast. Soc. Chang. 2011, 78, 991-1001. [CrossRef]

40. King, A. Diez años con el TLCAN. Revisión de la Literatura y Análisis de las Respuestas de los Agricultores de Sonora y Veracruz, México; (Informe Especial) Report No.: 07-01; CIMMYT: México City, Mexico, 2007.

41. CONEVAL. Evolución de las Líneas de Bienestar y d ela Canasta Alimentaria. 2016. Available online: http:/ / www.coneval.org.mx/Medicion/MP/Paginas/Lineas-de-bienestar-y-canasta-basica.aspxhttp:/ / www.coneval.gob.mx/Informes/Coordinacion/INFORMES_Y_PUBLICACIONES_PDF/Construccion_ lineas_bienestar.pdf (accessed on 1 July 2016).

42. Gobierno del Estado de Chiapas. Chiapas Nos Une. 2015. Available online: http://www.chiapas.gob.mx/ ubicacion (accessed on 26 January 2015).

43. INEGI. Encuesta Nacional Agropecuaria ENA 2014. Resultados. 2015. Available online: http:/ / www.inegi.org.mx/est/contenidos/proyectos/encuestas/agropecuarias/ena/ena2014/doc/ presentacion/ena2014_pres.pdf (accessed on 27 July 2016).

44. Fundación Produce Chiapas, A.C. Agenda Estatal de Innovación. In Programa de Desarrollo de Capacidades, Innovación Tecnológica y Extensionismo Rural Componente: Innovación y Transferencia de Tecnología; Fundación Produce Chiapas, A.C.: Tuxtla Gutiérrez, Mexico, 2011; p. 124.

45. Guevara, F.; Rodríguez, L.A.; Ovando, J.; Gómez, H.; Ocaña, M.D.J.; y Camacho, T.C. Implicaciones socioeconómicas y energéticas del uso y manejo de rastrojo en la región Frailesca, Chiapas. In Rastrojos: Manejo, uso y Mercado en el Centro y sur de México; Centro de Investigación Regional Norte Centro: México City, Mexico, 2013; pp. 37-91.

46. Ceieg. Secretaria de Planeación, Gestión Pública y Programa de Gobierno. 2015. Available online: http: / / www.ceieg.chiapas.go (accessed on 17 March 2016).

47. McWilliams, B.; Zilberman, D. Time of Technology Adoption and Learning by Using. Econ. Innov. New Technol. 1996, 4, 139-154. [CrossRef]

48. Lawless, F. Statistical Models and Methods for Lifetime Data, 2nd ed.; Wiley: New York, NY, USA, 1982; 664p.

49. Lancaster, K. The Econometric Analysis of Transition Data, 1st ed.; Cambrige University Press: Cambridge, UK, 1992; 352p.

50. Lancaster, K. The econometric analysis of transition data. Econ. J. 1992, 102, 165-166.

51. Bland, M.; Altman, G. Survival probabilities (the Kaplan-Meier method). Br. Med. J. 1998, 317, $1572-1580$. [CrossRef]

52. Cox, D. Regression models and life tables. J. R. Stat. Soc. 1972, 34, 187-220.

53. Allison, P.D. Discrete-time methods for the analysis of event histories. In Sociological Methodology Jossey-Leinhardt; Bass Publishers: San Francisco, CA, USA, 1982; pp. 61-98.

54. Feder, G.; Umali, D. The adoption of agricultural innovations. Technol. Forecast. Soc. Chang. 1993, 43, $215-239$. [CrossRef]

55. Bekele, A.; Abebe, Y. Analysis of adoption spell of hybrid maize in the Central Rift Valley, Oromyia National Regional State of Ethiopia: A duration model approach. J. Agric. Econ. Dev. 2014, 4, 207-213. [CrossRef]

56. Mwangi, H.W.; Kihurani, A.W.; Wesonga, J.M.; Ariga, E.S.; Kanampiu, F. Factors influencing adoption of cover crops for weed management in Machakos and Makueni counties of Kenya. Eur. J. Agron. 2015, 69, 1-9. [CrossRef]

57. Dhakal, A.; Cockfield, G.; Maraseni, T.N. Deriving an index of adoption rate and assessing factors affecting adoption of an agroforestry-based farming system in Dhanusha District, Nepal. Agrofor. Syst. 2015, 89, 645-661. [CrossRef] 
58. Islam, A.; Barman, B.; Murshed-e-Jahan, K. Adoption and impact of integrated rice-fish farming system in Bangladesh. Aquaculture 2015, 447, 76-85. [CrossRef]

59. Kallas, Z.; Serra, T.; Gil, J. Farmers' objectives as determinants of organic farming adoption: The case of Catalonian vineyard production. Agric. Econ. 2010, 41, 409-423. [CrossRef]

60. Smale, M.; Richard, J.; Howard, L. Land allocation in HYV adoption models: An investigation of alternative explanations. Agric. Am. J. Econ. 1994, 76, 535-546. [CrossRef]

61. Weber, C.; McCann, L. Adoption of nitrogen-efficient technologies by, U.S. corn farmers. J. Environ. Qual. 2015, 44, 391-401. [CrossRef] [PubMed]

62. Asfaw, S.; Shiferaw, B.; Simtowe, F.; Lipper, L. Impact of modern agricultural technologies on smallholder welfare: Evidence from Tanzania and Ethiopia. Food Policy 2012, 37, 283-295. [CrossRef]

63. Ghimire, R.; Wen-Chi, H.; Shrestha, B. Factors affecting adoption of improved rice varieties among rural farm households in Central Nepal. Rice Sci. 2015, 22, 35-43. [CrossRef]

64. Cavallo, E.; Ferrari, E.; Bollani, L.; Coccia, M. Attitudes and behaviour of adopters of technological innovations in agricultural tractors: A case study in Italian agricultural system. Agric. Syst. 2014, 130, 44-54. [CrossRef]

65. Howley, P.; Buckley, C.; Donoghue, C.O.; Ryan, M. Explaining the economic "irrationality" of farmers' land use behaviour: The role of productivist attitudes and non-pecuniary benefits. Ecol. Econ. 2015, 109, 186-193. [CrossRef]

66. Nandi, R.; Gowdru, N.; Bokelmann, W.; Dias, G. Smallholder organic farmer's attitudes, objectives and barriers towards production of organic fruits and vegetables in India: A multivariate analysis. Emir. J. Food Agric. 2015, 17, 396-406. [CrossRef]

67. Hair, J.; Anderson, E.; Tatham, R.; Black, W. Multivarte Data Analysis; Internationa Prentice-Hall International Inc.: Upper Saddle River, NJ, USA, 1998; 730p.

68. Valdivia, R.; Espinosa, A.; Tadeo, M.; Caro, F.; Aguilar, J.; Vidal, V.; Ruelas, P.; López, G. “Cora 2012”: Híbrido intervarietal de maíz para Nayarit y regiones similares. Rev. Mex. Cienc. Agríc. 2015, 6, 417-420.

69. Valdivia, R.; Caro, F.; Ortiz, M.; Betancourt, A.; Ortega, A.; Vidal, V.; Espinosa, A. Desarrollo participativo de híbridos sintéticos de maíz y producción de semilla por agricultores. Agric. Téc. Méx. 2007, 33, 135-143.

70. Hellin, J.; Bellon, M. Manejo de semillas y diversidad del maíz-AgriCultures Network. Leisa Rev. Agroecol. 2007, 23, 9-11.

71. Salazar, J.; Rivera, H.; Arévalo, S.; Guevara, A.; Mald, G.; Raascón, Q. Calidad del nixtamal y su relación con el ambiente de cultivo del maíz. Fitotec. Mex. 2015, 38, 67-73.

72. Birol, E.; Smale, M.; Yorobe, J. Bi-modal preferences for bt maize in the Philippines: A latent class model. AgBioForum 2012, 15, 175-190.

73. Li, J.; Lammerts, E.; Jiggins, J.; Leeuwis, C. Farmers' adoption of maize (Zea mays, L.) hybrids and the persistence of landraces in Southwest China: Implications for policy and breeding. Genet. Resour. Crop Evol. 2012, 59, 1147-1160. [CrossRef]

74. Sibiya, J.; Tongoona, P.; Derera, J.; Makandaa, I. Farmers' desired traits and selection criteria for maize varieties and their implications for maize breeding: A case study from Kwazulu-Natal Province, South Africa. J. Agric. Rural Dev. Trop. Subtrop. 2013, 114, 39-49.

75. Veisi, H.; Liaghati, H.; Alipour, A. Developing an ethics-based approach to indicators of sustainable agriculture using analytic hierarchy process (AHP). Ecol. Indic. 2016, 60, 644-654. [CrossRef]

76. Asrat, S.; Yesuf, M.; Carlsson, F.; Wale, E. Farmers' preferences for crop variety traits: Lessons for on-farm conservation and technology adoption. Ecol. Econ. 2010, 69, 2394-2401. [CrossRef]

77. Kamara, A.; Kureh, I.; Menkir, A.; Kartung, P.; Tarfa, B.; Amaza, P. Participatory on-farm evaluation of the performance of drought-tolerant maize varieties in the Guinea savannas of Nigeria. Int. J. Food Agric. Environ. 2006, 4, 192-196.

78. Yúnez, A.; Barceinas, F. The Agriculture of Mexico after Ten Years of Nafta Implementation; Documentos de Trabajo; Banco Central de Chile: Santiago, Chile, 2004.

79. Kiefer, N. Economic duration data and hazard functions. J. Econ. Lit. 1988, 26, 646-679.

80. Nazli, H.; Smale, M. Dynamics of variety change on wheat farms in Pakistan: A duration analysis. Food Policy 2016, 59, 24-33. [CrossRef]

81. Rogers, E. Diffusion of Innovations, 4th ed.; T.F. Press: New York, NY, USA, 1995. 
82. Abdulai, A.; Huffman, E. The diffusion of new agricultural technologies: The case of crossbred-cow technology in Tanzania. Am. J. Agric. Econ. 2005, 87, 645-659. [CrossRef]

83. Negatu, W.; Parikh, A. The impact of perception and other factors on the adoption of agricultural technology in the Moret and Jiru Woreda (district) of Ethiopia. Agric. Econ. 1999, 21, 205-216. [CrossRef]

84. Rogers, E.M. Lessons for guidelines from the diffusion of innovations. Joint Comm. J. Quality Patient Saf. 1995, 21, 324-328. [CrossRef]

85. Parra, C.; Calatrava, R. Factors related to the adoption of organic farming in Spanish olive orchards. Span. J. Agric. Res. 2005, 3, 5-16. [CrossRef]

86. Gaytan, R.; Reyes, L.; Martínez, M.; Mayek, N.; Padilla, S.Y.; Luna, F. Seed and forage yield depression of maize hybrids in advanced generations. Agric. Téc. Méx. 2005, 31, 165-175.

87. Lunduka, R.; Fisher, M.; Snapp, S. Could farmer interest in a diversity of seed attributes explain adoption plateaus for modern maize varieties in Malawi? Food Policy 2012, 37, 504-510. [CrossRef]

88. Kafle, B. Determinants of adoption of improved maize varieties in developing countries: A review. Int. Res. J. Appl. Basic Sci. 2010, 1, 1-7.

89. Ouma, J.; Bett, E.; Mbataru, P. Drivers of adoption of Improved Maize varieties in Moist Transitional zone of Eastern Kenya. J. Econ. Sustain. Dev. 2014, 5, 1700-2222.

90. Simtowe, F.; Zeller, M.; Diagne, A. The impact of credit constraints on the adoption of hybrid maize in Malawi. Rev. Agric. Environ. Stud. 2009, 90, 5-22.

91. Mignouna, D.; Manyong, V.; Rusike, J.; Mutabazi, K.; Senkondo, E. Determinants of Adopting Imazapyr-Resistant Maize Technologies and its Impact on Household Income in Western Kenya. J. Agrobiotechnol. Manag. Econ. 2011, 14, 7.

92. Nadal, A.; Wise, T. Working Group on Development and Environment in the Americas the Environmental Costs of Agricultural Trade Liberalization: Mexico-U.S. Maize Trade under NAFTA; Discussion Paper Number 4; Working Group on Development and Environment in the Americas; 2004. Available online: https:/ / www.researchgate.net/publication/237616381_The_Environmental_Costs_of_Agricultural_ Trade_Liberalization_Mexico-S_Maize_Under_NAFTA_Working_Group_on_Environment_and_ Development_in_the_Americas_March_29-30_2004 (accessed on 20 September 2018).

93. Nadal, A. The Environmental and Social Impacts of Economic Liberalization on Corn Production in Mexico; Estudio Realizado por Oxfam GB y WWF International: Oxford, UK, 2000.

94. Di-Falco, S.; Bulte, E. A dark side of social capital? kinship, consumption, and savings. J. Dev. Stud. 2011, 47, 1128-1151. [CrossRef]

95. Mafuru, J.; Kileo, R.; Verkuijl, H.; Mwangi, W.; Anandajaysekeram, P.; Moshi, A. Adoption of Maize Production Technologies in the Lake Zone of Tanzania; CIMMYT: México City, Mexico, 1999; 39p.

96. Noltze, M.; Schwarze, S.; Qaim, M. Understanding the adoption of system technologies in smallholder agriculture: The system of rice intensification (SRI) in Timor Leste. Agric. Syst. 2012, 108, 64-73. [CrossRef]

97. Dibba, L.; Zeller, M.; Diagne, A.; Nielsen, T. How accessibility to seeds affects the potential adoption of an improved rice variety: The case of the new rice for Africa (NERICA) in the Gambia. Q. J. Int. Agric. 2015, 54, 33-58.

98. Kallas, Z.; Serra, T.; Gil, J. Farmer's objectives as determinant factors of organic farming adoption. In Proceedings of the 113th EAAE Seminar "A Resilient European Food Industry and Food Chain in a Challenging World", Chania, Greece, 3-6 September 2009; p. 19.

99. Becerril, J.; Abdulai, A. The Impact of improved maize varieties on poverty in Mexico: A propensity score-matching approach. World Dev. 2010, 38, 1024-1035. [CrossRef]

100. Brick, K.; Visser, M. Risk preferences, technology adoption and insurance uptake: A framed experiment. J. Econ. Behav. Organ. 2015, 118, 383-396. [CrossRef]

101. Albert, S.; Duffy, J. Differences in risk aversion between young and alder adults. Neurosci. Neuroecon. 2012, 2, 3-9. [CrossRef] [PubMed]

102. Dohmen, T.; Falk, A.; Huffman, D.; Sunde, U. Are risk aversion and impatience related to cognitive ability? Am. Econ. Rev. 2010, 100, 1238-1260. [CrossRef]

(C) 2018 by the authors. Licensee MDPI, Basel, Switzerland. This article is an open access article distributed under the terms and conditions of the Creative Commons Attribution (CC BY) license (http:/ / creativecommons.org/licenses/by/4.0/). 